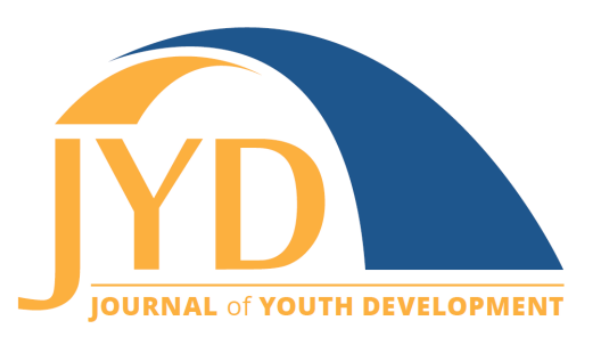

http://jyd. pitt. edu/ | Vol. 14 Issue 3 DOI 10.5195/jyd.2019.639 | ISSN 2325-4017 (online)

\title{
Partner Build Grow: Resources to Sustain Partnerships and Advance Prevention Initiatives
}

\author{
Evelyn Frankford \\ Frankford Consulting \\ evelyn.frankford@gmail.com
}

\section{Rachel Sadlon}

The George Washington University rachelsadlon@gwu.edu

\section{Olga Acosta Price}

The George Washington University

oaprice@gwu.edu

\section{Linda Sheriff}

The George Washington University

Ibsheriff@gwu.edu

\begin{abstract}
Alignment of programs, practices, and policies by practitioners at the state and local levels can create health-promoting environments for all children. Such alignment, guided by principles of prevention science and public health, can enhance school-community partnerships involved with the mental, emotional, and behavioral well-being and positive development of children and youth. The key to success of such prevention approaches is sustaining the work over time. Partner Build Grow, an online Action Guide, supports sustainability through cross-sector collaborations and systems change to create schoolcommunity environments that promote equity. Informed by local and national experts along with field experience and application of best practices, Partner Build Grow presents a framework and provides the support to guide schools and communities through a process to build and sustain school-community partnerships. The Action Guide identifies four components critical for sustainability: Building an Action Team, Mapping Assets, Connecting With the Policy Environment, and Building a Communications Plan, and provides practical implementation tools for each area that can be customized for local contexts. Since the August 2015 Action Guide launch, we have tracked Web page views, unique users, registrants, and other analytics to measure engagement. Partner Build Grow presents Web-based resources and tools for local and state cross-sector collaboration to sustain effective practices and systems for positive and healthy youth development.
\end{abstract}

(c) $\mathrm{EY}_{\mathrm{EY}}$ New articles in this journal are licensed under a Creative Commons Attribution 4.0 License. This journal is published by the University Library System, University of Pittsburgh and is cosponsored by the University of Pittsburgh Press. The Journal of Youth Development is the official peer-reviewed publication of the National Association of Extension 4-H Agents and the National AfterSchool Association. 
Key words: youth development, school-community partnerships, systems change, prevention, sustainability

\section{An Opportunity to Improve Child Well-Being}

Social determinants, the environmental, physical, and economic conditions in which one lives, works, learns, and plays, are strong predictors of child outcomes, including general health and education. When a child's environment includes exposure to acute or chronic adverse experiences, the probability of a positive outcome decreases (Acevedo Garcia, Rosenfeld, McArdle, \& Osypuk, 2010; Hoagwood et al., 2018; Pascoe, Wood, Duffee, \& Kuo, 2016). Unfortunately, the number of children in the United States trying to thrive in risky conditions is large and continues to grow. Of American children from birth to age 17, more than $45 \%$ have had at least one parent-reported adverse childhood experience, such as the death of a parent, witnessing abuse in the home, food scarcity or homelessness, living with someone who abused drugs or alcohol, or being exposed to violence (Sacks \& Murphey, 2018). More than half of all U.S. public school children receive free and reduced-price lunch, a frequent proxy for communities experiencing high levels of poverty, signaling a need to acknowledge poverty's many associated social and economic challenges (Southern Education Foundation, 2015). These students face headwinds of a multiple and systemic nature, which undermines the country's ability to produce the next generation of educated citizens.

The formative periods of childhood and adolescence are therefore an optimal time for mitigating the impact of these adverse conditions by providing youth with the skills, environments, and knowledge to counter these headwinds (National Research Council, 2009). Schools represent one important context that wields long-term influence on child cognitive and social development (Atkins, Hoagwood, Kutash, \& Seidman, 2010). In collaboration with community partners, they are in a position to advance prevention and health promotion and thereby buffer the effects of their environments. Teachers, school administrators, youth program directors and workers, and other personnel in schools and community organizations are on the front lines, observing behaviors and situations exacerbated by social conditions beyond any one individual's control. These adults, who interact on a regular basis with students, seek resources and guidance to promote the teaching, learning and positive development of young people.

Many schools and community organizations partner to tackle identified problems and strengthen children's education and development (Blank, 2015; Bronstein \& Mason, 2016; Henig, Riehl, 


\section{Partner Build Grow}

Houston, Rebell, \& Wolf, 2016; Valli, Stefanski, \& Jacobson, 2016). Unfortunately, these partnerships frequently pursue paths that require funding through grants and other external means and they often dissolve once the funding ends. An alternative approach is to build, coordinate, align, and sustain these crucial services in ways that offer continuous assistance to students, particularly those in high-poverty areas.

\section{Partner Build Grow: An Action Guide for Sustaining Child Development and Prevention} Approaches is a free, online resource that provides guidance to educators, practitioners, and decision-makers on this alternative path of aligning school and community resources and sustaining these efforts through collaboration and systems change. Developed by the Center for Health and Health Care in Schools (CHHCS) in the Milken Institute School of Public Health at the George Washington University, Partner Build Grow provides practical steps, tools, and success stories to assist school and community stakeholders in developing plans to maintain, strengthen, and align programs that give children the skills they need to flourish. Central to Partner Build Grow is a recognition that every community is unique and should select the programs and services that benefit their children; however, the process of developing a coordinated system that supports healthy child development is similar across communities. Partner Build Grow presents a framework and provides the support to guide schools and communities through that process.

\section{Methodology for Creating the Action Guide}

The idea for building a Web-based Action Guide emerged from the deep knowledge CHHCS acquired over $30+$ years as a national technical assistance center supporting numerous schoolcommunity initiatives across the United States. As a technical assistance provider collaborating with a large national foundation to implement four multi-site, multi-year, school-connected grant initiatives, the developers gained valuable insights into the factors that increase the likelihood that projects focused on student health and academic success endure. Building on these lessons learned and using their unique public health lens, the developers examined strategies for incorporating the prevention-science knowledge base, scanned the current prevention and school-community partnership literatures, gained knowledge of systems change strategies, and reviewed existing resources and tools to craft Partner Build Grow as a unique resource for focusing on social determinants.

The developers also incorporated some findings from two qualitative research projects of their own. In the first, we interviewed 44 key informants in nine states that either had a successful, 


\section{Partner Build Grow}

statewide social-emotional learning (SEL) program or had districts that were part of a larger SEL initiative, SEL constituting one piece of a larger school-community approach. This field research, conducted with state and local leaders, revealed the importance of champions and early adopters across multiple sectors who can evolve into a small, committed leadership team. In the second field research project, we convened day-long structured community conversations with leaders in four communities at various stages of the systems change process for sustaining strong, multidisciplinary, school-community initiatives. Details of both studies will be reported elsewhere, but a key finding was that to achieve sustainability, the focus should not be on programs but rather on supporting a process for systemic change (O. A. Price, personal communication, July 1,2018$)$.

\section{Findings}

The developers examined available frameworks, tools, and strategies that could help practitioners, program directors, and decision-makers, in local partnerships and at state-level interagency groups, build and sustain population-based approaches to child development and mental health promotion in school-community venues. Each of the reviewed frameworks, tools, and strategies made a unique contribution to the development of the online guide, helping us to understand essential factors as well as shortcomings in popular approaches. But none had all the features we sought. Existing frameworks on establishing school-community partnerships emphasize a focus on improving integration between health and education practices to benefit the "whole child." But none provide explicit guidance on how to build and sustain broader crosssector initiatives that involve, but may not be led by, the education sector. Nor did they outline strategies for addressing the underlying determinants of health and education that impact "whole communities."

Absent occasional hands-on technical assistance projects, there is little practical advice on how to implement sustainable school-community partnerships to promote child social, emotional, and cognitive development and mental health over the long term. We concluded that most comprehensive prevention frameworks, strategies, and tools focus almost exclusively on what they wanted stakeholders to do with little to no guidance offered on how they could get there.

With these key findings in hand, we sought to devise an accessible, Web-based resource for prevention-oriented, school-community collaborations, whether locally led or state-driven, that would demystify the process and require minimal hands-on technical assistance to implement. Given the complexity of this task, we determined that the Web resource should first help 


\section{Partner Build Grow}

stakeholders use the content knowledge about child social, emotional, and cognitive development; mental health promotion and prevention; and school-community partnerships that integrate them; and second, provide guidance on the "how-to" of systems change and capacity-building for sustainability. This became Partner Build Grow.

\section{Essential Components of the Action Guide}

Our exploration ultimately led us to the four essential components of a sustainable schoolcommunity approach to advance a prevention agenda to promote child health and academic success: Building an Action Team, Mapping Assets, Connecting with the Policy Environment, and Building a Communications Plan. Furthermore, we saw that the relationships among these components are fundamental for successful execution of the work (Stroh, 2015) (refer to Figure 1). Table 1 provides a description and brief characteristics for each prong of the Action Guide.

Figure 1. Framework for Sustainability: The Four-Pronged Model

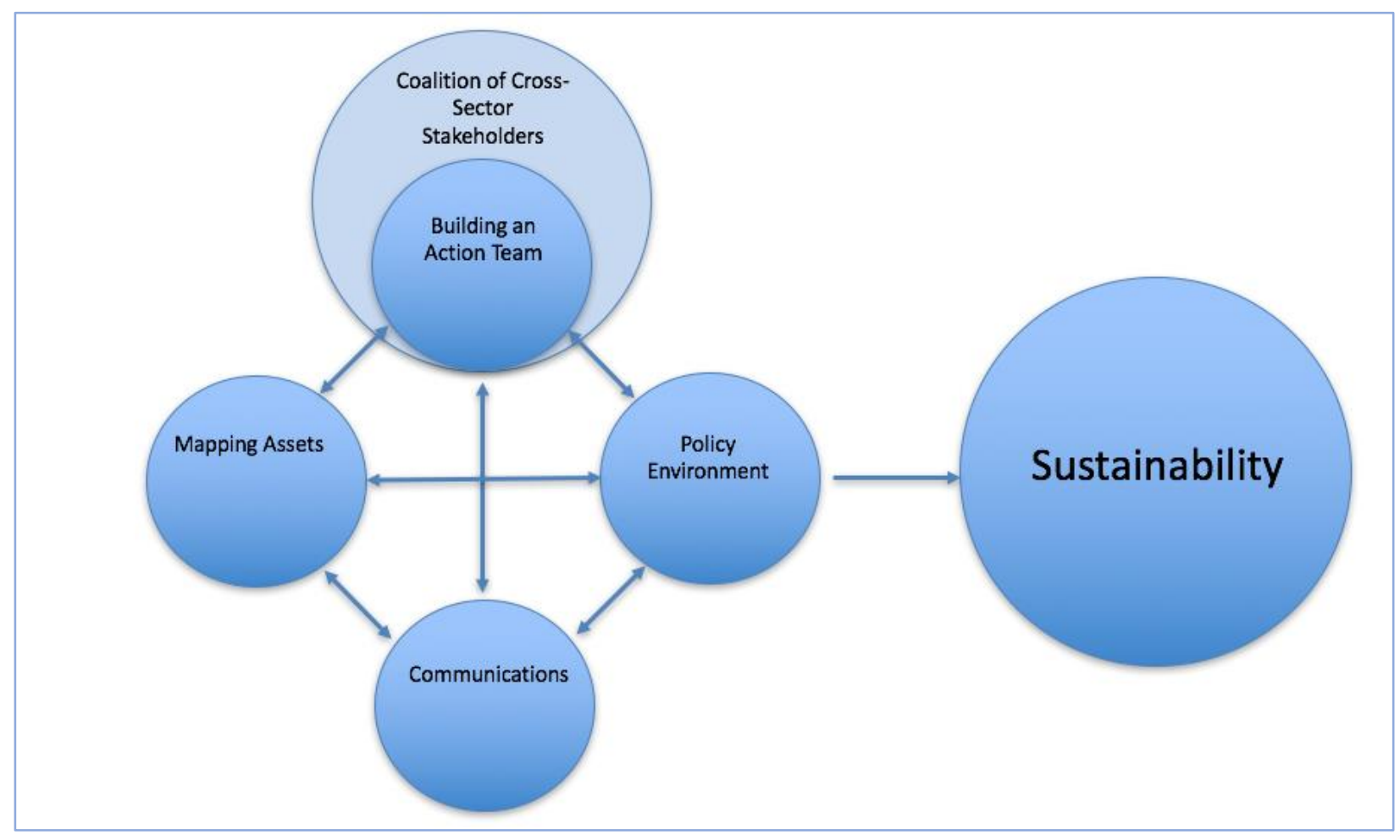


Partner Build Grow

Table 1. Key Activities of the Four Action Guide Prongs

\begin{tabular}{|c|c|c|}
\hline Prong & Definition & Actions \\
\hline $\begin{array}{l}\text { Building an } \\
\text { Action Team }\end{array}$ & $\begin{array}{l}\text { A leadership group that } \\
\text { prioritizes networking and } \\
\text { building/strengthening } \\
\text { relationships with anyone who } \\
\text { might share the particular } \\
\text { initiative's goals; members have } \\
\text { political clout, and are able to } \\
\text { navigate the complexities of } \\
\text { policy and procedure change } \\
\text { and funding. }\end{array}$ & $\begin{array}{l}\text { - Identify cross-sector partners and work to } \\
\text { define the network. } \\
\text { - Identify membership. } \\
\text { - } \text { Define roles and responsibilities. } \\
\text { - } \text { Eeverage the capacities of stakeholders. } \\
\text { - } \text { Devise strategies and tactics. } \\
\text { - Utilize individuals' connections to policy } \\
\text { processes. } \\
\text { - Serve as the public face of the initiative, } \\
\text { speak at public hearings, etc. }\end{array}$ \\
\hline Mapping Assets & $\begin{array}{l}\text { A process that shows what } \\
\text { school and community } \\
\text { resources are currently in place } \\
\text { and where they are located; } \\
\text { also, shows levels of effort (in } \\
\text { dollars, users, or other } \\
\text { measures). A goal is to align } \\
\text { them for maximum leverage. }\end{array}$ & $\begin{array}{l}\text { - Engage multi-sector collaboration. } \\
\text { address questions of data, identify gaps, } \\
\text { - Use data to determine whether and how to } \\
\text { reorganize resources to greater effect or } \\
\text { what other resources to seek. } \\
\text { - Utilize population data (publicly-available, } \\
\text { non-personally-identifying). } \\
\text { - May use spatial data from Geographic } \\
\text { Information Systems (GIS). } \\
\text { Build a foundation of interconnected } \\
\text { resources, an infrastructure upon which } \\
\text { additional layers can be added. }\end{array}$ \\
\hline
\end{tabular}


Table 1 (continued)

\begin{tabular}{|c|c|c|}
\hline Prong & Definition & Actions \\
\hline $\begin{array}{l}\text { Policy } \\
\text { Environment }\end{array}$ & $\begin{array}{l}\text { Effecting systems change } \\
\text { through engagement with } \\
\text { statutes, policies, regulations, } \\
\text { and procedures and seeking } \\
\text { opportunities to influence or } \\
\text { connect initiatives to them. } \\
\text { Stakeholders understand not } \\
\text { only how and when policy } \\
\text { changes are made and how } \\
\text { initiatives are funded, but the } \\
\text { priorities and movements that } \\
\text { can be influenced, how to } \\
\text { address any policy or procedure } \\
\text { changes necessary for the } \\
\text { sustainability of an initiative, } \\
\text { and how to capitalize on } \\
\text { emerging funding streams. }\end{array}$ & $\begin{array}{l}\text { - Interact with the processes of making } \\
\text { policies, regulations, and procedures. } \\
\text { - Remain up to date to quickly jump on } \\
\text { opportunities. } \\
\text { - Keep abreast of the policy and funding } \\
\text { opportunities that may arise at the macro } \\
\text { level (e.g., health care reform). } \\
\text { - Show how strength-based resources fit into } \\
\text { the bigger picture. } \\
\text { - Understand the budget process and track } \\
\text { funding streams. } \\
\text { - Participate in cross-systems initiatives to } \\
\text { help shape them and be able to take } \\
\text { advantage of possibilities that arise. }\end{array}$ \\
\hline Communications & $\begin{array}{l}\text { A communications plan to build } \\
\text { and sustain support for your } \\
\text { initiative. }\end{array}$ & $\begin{array}{l}\text { - Develop a set of core messages and talking } \\
\text { points. } \\
\text { - Use a consistent vocabulary. } \\
\text { - Identify target audiences. } \\
\text { - Figure out specific and do-able "asks" for } \\
\text { each target audience. } \\
\text { - Determine the best way to reach those } \\
\text { audiences and who the "messengers" will } \\
\text { be for various public and interpersonal } \\
\text { tasks. }\end{array}$ \\
\hline
\end{tabular}

\section{The Action Guide Design}

Generic materials can have impact in fostering organizational change when users can also tailor them to their own situations (Veatch, Goldstein, Sacks, Lent, \& Van Wye, 2014). The developers determined to find ways for stakeholders to customize the resource to make it as effective as 


\section{Partner Build Grow}

possible. In this way, we sought to maximize the opportunities of online, rather than in-person, technical assistance. Furthermore, an online structure supports the interconnected relationship of the prongs, making it easier to highlight their linkages and how they build on each other rather than setting up a linear, step-by-step process.

For this reason, we determined that each prong should have its own section that provided general guidance and principles while allowing room for customization. Action Guide users can easily navigate the Web pages by selecting a prong which corresponds with their strategy of focus (Figure 2).

Figure 2. Screenshots of Partner Build Grow Website

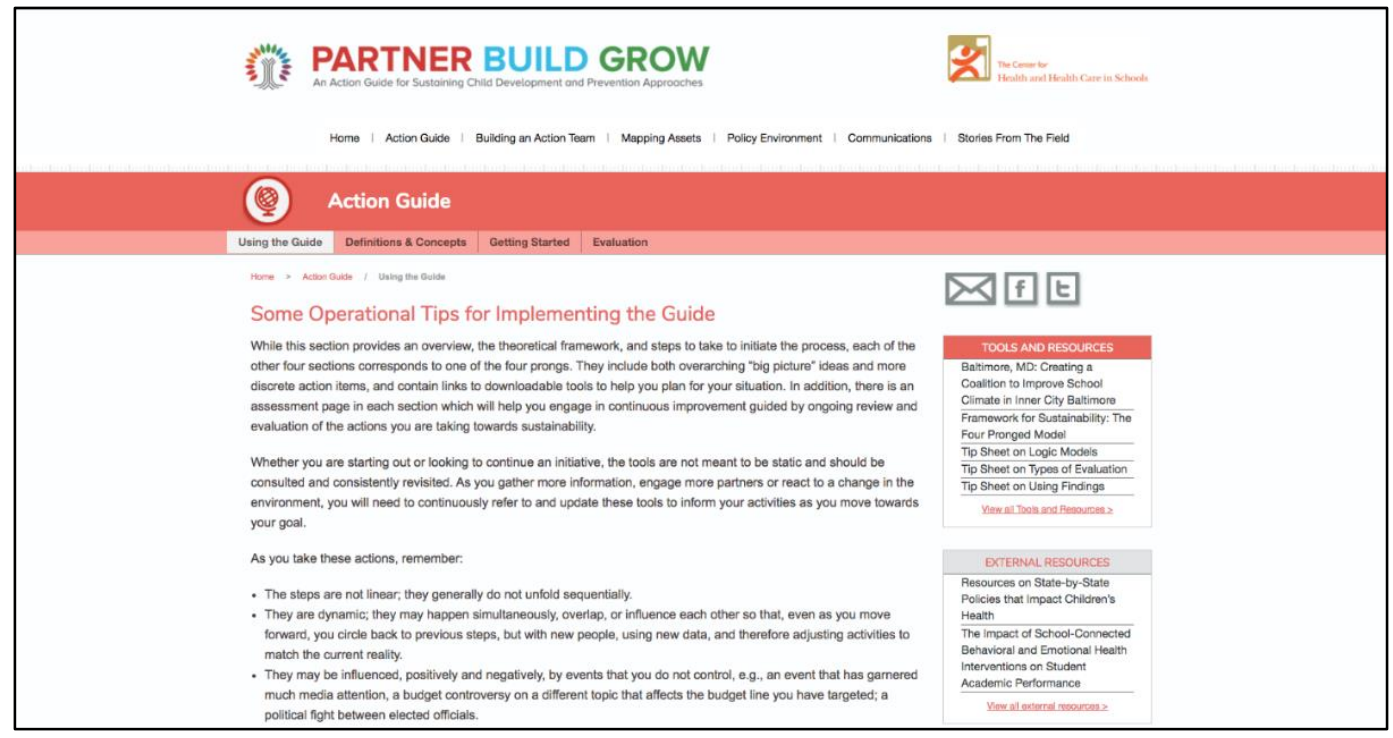

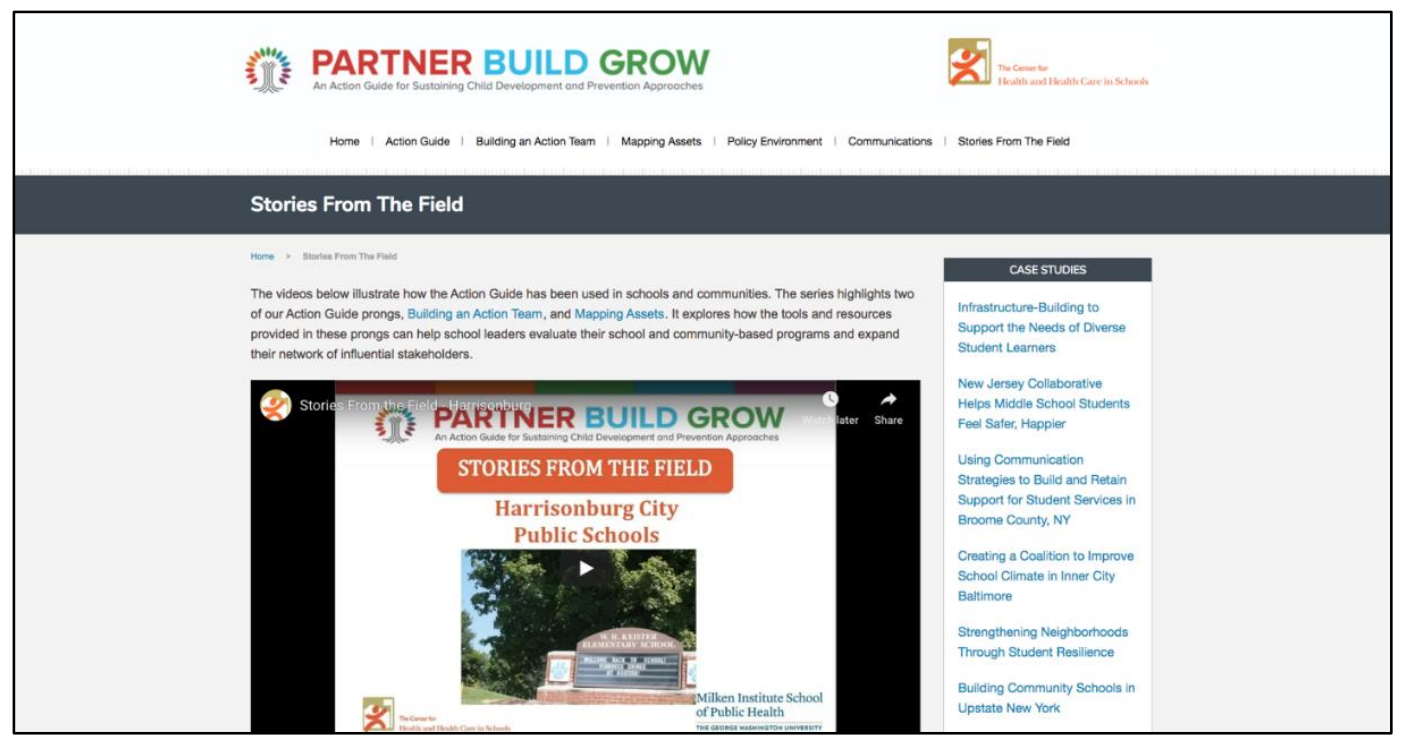




\section{Partner Build Grow}

Guiding Questions are included for each prong to provide initial but deep direction to schoolcommunity collaborators. In Communications, for example, users are encouraged to broadly consider developing a shared vision, identify key audiences and messengers, and think about needed materials and resources.

This guidance is reinforced with a list of Key Actions, supplemented by worksheets for downloading and individualized use by Action Teams and coalition partners. The Action Guide contains free downloadable and editable templates and worksheets to facilitate planning around systems change. For example, accompanying the guidance around Building an Action Team is the worksheet "Identifying Potential Partners," where team members can review, identify, and plan to engage possible individuals, agencies, organizations, or local groups from the community to be considered as a group forms or strengthens their coalition. As of February 2018, the Action Guide contains 10 different tools and templates that can be customized for local users.

With sustainability the ultimate goal of school-community partnerships, the Action Guide encourages users to "begin with the end in mind." Each prong concludes with a section devoted to assessment, to guide stakeholders in evaluating if and how they are moving forward toward their goals and objectives and how to correct course if they have taken a detour. These sections direct users toward continuous improvement by providing questions that serve as a starting point for assessing progress.

\section{Examples}

The availability of real-world examples makes effective action more likely (Baker, 2011). Therefore, we populated the website with case studies developed from real-life experiences from school-community coalitions, showcasing results that illustrate how the prongs move a public health agenda forward.

Broome County, New York utilized several of the Action Guide prongs concurrently to build its unique county-wide community school model. Facilitated by Binghamton University, a core team engaged school superintendents, elected officials, local law enforcement, and local community agency partners in developing a shared vision. A community conversation with these stakeholders was deemed a great success and resulted in several follow up activities to continue the sustainability planning for their school-community partnership initiative. A director of the community coalition stated: 
Partner Build Grow

All members expressed an interest in a follow-up meeting to continue the conversations and planning the work forward. This

was especially telling to me since the room was full of very busy

people who are never at a shortage of demands on their time.

Having created a "backbone" coalition, Broome County officials took advantage of an existing policy opportunity to obtain ongoing state funding to pay for core infrastructure to sustain the larger project.

Other examples are documented in case studies. In New Hampshire, a diverse coalition included leaders in the funding world who facilitated project leaders' access to important conversations about larger state policy questions affecting children's well-being. Other case studies illustrate that such collective action takes time; that it's valuable to have a mix of funders and people doing the work (Morristown, New Jersey); that asset mapping-as one called it, "creating a landscape map"-helps to identify who is already doing some of the work (Vancouver, Washington); and that an alignment of several disparate initiatives can produce a more coherent set of activities (Baltimore, Maryland).

The developers update Partner Build Grow often to include stories of localities using the prongs. Most recently, short videos from Harrisonburg, Virginia and Cincinnati, Ohio were added to explain how these communities have used Building an Action Team and Mapping Assets, respectively. Partner Build Grow can guide youth development professionals, in partnership with health, education, and other relevant stakeholders, to create or enhance sustained schoolcommunity partnerships that support the mental, emotional, and behavioral well-being and positive development of children and youth.

\section{Stakeholder Feedback and Dissemination}

The site launched in August 2015 and numerous dissemination activities were completed. In early 2016, the developers sent announcements about the Action Guide through mailing lists to approximately 6,000 health and education professionals. We hosted a webinar about the Action Guide in January 2016 that drew significant interest (196 registrants and 101 participants) and $79 \%$ of the 33 post-webinar survey respondents reported a desire to participate in future webinars about the Action Guide. Participants were from 31 states and Washington, D.C., and from one country outside of the United States. Two webinars in February 2016 introduced the tools and resources associated with the Mapping Assets and Communications sections of the Action Guide Participant feedback substantiated community need for such a guide. 
Within two years of the site going live, the developers presented on the Action Guide at five national conferences or regional meetings on cross-sector topics, including education, mental health, public health, and community schools, with a focus alternately on policy, practice, local operations, and evaluation, and received affirmative feedback from participants. Throughout this time, the website's visibility among stakeholders working in the education and health fields has steadily increased to reach 89,782 page views from nearly 12,000 unique users. As of February 2019, 57 users have registered on the site and analytics reveal an average page view rate of 5.81 pages per session.

\section{Conclusions and Next Steps}

Even as knowledge about prevention has burgeoned, formal pipelines are scarce for getting this knowledge and attendant positive child development practices into the institutions that serve children. But this gap is also an opportunity: Across the United States, partnerships between schools and community organizations have become normative in efforts to tackle identified problems and strengthen children's education and development (Blank, 2015; Bronstein \& Mason, 2016; Henig et al., 2016; Valli et al., 2016).

While cross-agency collaboration is inherently complex and taxing, such partnerships are among the few available strategies for reaching school-age children and adolescents and for improving their social, physical, and economic environments.

Professionals in the fields of public health, education, social work, and youth development have the opportunity to infuse prevention knowledge into the many venues that make up the socialenvironmental context of young people. One key to success will be the ability of partners to pivot away from the search for programs to remedy specific problems toward systemic solutions and strategies focused on social-ecological determinants.

Effective and sustainable child development and prevention initiatives require schoolcommunity partners to focus on populations rather than individuals and on changing environments rather than people's behavior. That, in turn, requires a focus on the organizational and policy changes that can produce better alignment of resources to achieve sustainability. Achieving that goal requires, in turn, the dissemination of both bottom-up 


\section{Partner Build Grow}

strategies of local and state stakeholders and top-down, widespread support from important organizational influencers among child-serving institutions.

Schools and communities are working hard to help children thrive-academically, physically, and mentally. While specific programmatic guidance is available, there is less focus on the process schools and communities should take to align their resources to reach their goals. The Action Guide, Partner Build Grow, offers a framework, Web-based resources, practical steps, and tools for each community to look at systems-level solutions to advance healthy child and youth development in their community.

\section{References}

Acevedo Garcia, D., Rosenfeld, L. E., McArdle, N., \& Osypuk, T. L. (2010). A geography of opportunity framework for child development. In C. Edley, \& J. Ruiz de Velasco (Eds.), Changing places: How communities will improve the health of boys of color (pp. 358-406). Berkeley, CA: University of California Press.

Atkins, M. S., Hoagwood, K. E., Kutash, K., \& Seidman, E. (2010). Toward the integration of education and mental health in schools. Administration and Policy in Mental Health and Mental Health Services Research, 37(1-2), 40-47. doi:10.1007/s10488-010-0299-7

Baker, G. R. (2011). The contribution of case study research to knowledge of how to improve quality of care. BMJ Quality \& Safety, 20, i30-i35. doi:10.1136/bmjqs.2010.046490

Blank, M. J. (2015). Building sustainable health and education partnerships: Stories from local communities. Journal of School Health, 85(11), 810-816. doi:10.1111/josh.12311

Bronstein, L. R., \& Mason, S. E. (2016). School-linked services: Promoting equity for children, families and communities. New York, NY: Columbia University Press.

Henig, J., Riehl, C., Houston, D., Rebell, M., \& Wolff, J. (2016). Collective impact and the new generation of cross-sector collaborations for education: A nationwide scan. New York, NY: Columbia University. Retrieved from http://www.wallacefoundation.org/knowledgecenter/Documents/Collective-Impact-and-the-New-Generation-of-Cross-Sector-Collaboration-forEducation.pdf

Hoagwood, K. E., Rotheram-Borus, M. J., McCabe, M. A., Counts, N., Belcher, H. M. E., Walker, D. K., \& Johnson, K. A. (2018). The interdependence of families, communities, and children's health: Public investments that strengthen families and communities, and promote children's healthy development and societal prosperity. (Discussion Paper). Washington, DC: National Academy of Medicine. Retrieved from https://nam.edu/the-interdependence-of-families-communities-and- 


\section{Partner Build Grow}

childrens-health-public-investments-that-strengthen-families-and-communities-and-promotechildrens-healthy-development-and-societal-prosperity

National Research Council and Institute of Medicine. (2009). Preventing mental, emotional, and behavioral disorders among young people: Progress and possibilities. Committee on Prevention of Mental Disorders and Substance Abuse Among Children, Youth, and Young Adults: Research Advances and Promising Interventions. M. E. O'Connell, T. Boat, \& K. E. Warner (Eds.). Board on Children, Youth, and Families, Division of Behavioral and Social Sciences and Education. Washington, DC: National Academies Press. doi:10.17226/12480

Pascoe, J. M., Wood, D. L., Duffee, J. H., \& Kuo, A. (2016). Mediators and adverse effects of child poverty in the United States. Pediatrics, 1374), e1-e17. doi:10.1542/peds.2016-0340

Sacks, V. \& Murphey, D. (2018). The prevalence of adverse childhood experiences, nationally, by state, and by race/ethnicity. (Research Brief \#2018-03). Bethesda, MD: Child Trends. Retrieved from https://www.childtrends.org/publications/prevalence-adverse-childhood-experiences-nationallystate-race-ethnicity

Southern Education Foundation. (2015). A new majority: Low income students in the south and nation. (Research Bulletin). Retrieved from https://www.southerneducation.org/publications/newmajorityupdate/

Stroh, D. P. (2015). Systems thinking for social change: A practical guide to solving complex problems, avoiding unintended consequences, and achieving lasting results. White River Junction, VT: Chelsea Green Publishing.

Valli, L., Stefanski, A., \& Jacobson, R. (2016). Typologizing school-community partnerships. Urban Education, 51(7), 719-747. doi:10.1177/0042085914549366

Veatch, M., Goldstein, G. P., Sacks, R., Lent, M., \& Van Wye, G. (2014). Institution-to-institution mentoring to build capacity in 24 local US health Departments: Best practices and lessons learned. Preventing Chronic Disease, 11, E168. doi.org/10.5888/pcd11.140017 